\title{
Presença $v s$ ausência de traços de ruralidade no léxico tocantinense
}

\author{
[ Presence vs absence of traces of rurality in the lexicon of Tocantins
}

\author{
Greize Alves da Silva ${ }^{\mathrm{I}}$ \\ Patrícia Andréa Borges ${ }^{2}$
}

RESUMO - Até o início do século XX, o Brasil era essencialmente um país rural, dinâmica que tem se modificado com as novas vias de comunicações. Os agricultores têm se deslocado para os grandes centros em busca de melhores oportunidades. Esse processo marca uma nova configuração social e, consequentemente, linguística, visto que o falante, no ambiente citadino, se submete a uma nova situação dialetal, muitas vezes marcada por processos de desenraizamento linguístico. Discute-se a manutenção ou perda de marcas lexicais conceituadas como rurais, a partir da análise dos dados coletados pelo Atlas Linguístico Topodinâmico e Topoestático do Estado do Tocantins (20I8), em I2 localidades do Tocantins, junto a 96 informantes estratificados por sexo, idade e tipo de mobilidade. - PALAVRAS-CHAVE - Léxico rural; ALiTTETO; comunidades rurbanas. - ABSTRACT $\cdot$ Up to the early $20^{\text {th }}$ century, Brazil was preponderantly a rural country. These status has changed due to the new communication routes. Farmers have transferred themselves to the great urban centers in search of better opportunities. The process has frequently impacted social attitudes and, consequently, a different linguistic stance. In the city milieu, the speaker encounters a new dialectical situation which is often marked by linguistic uprooting processes. A discussion ensues on the maintenance or loss of lexical markings, characterized as rural, on data collected in I2 sites in Tocantins, Brazil, from 96 informants stratified by gender, age and type of mobility, from the Topodynamic and Topostatic Linguistic Atlas of the State of Tocantins. • KEYWORDS - Rural lexicon; ALiTTETO; ruralurban communities.

Recebido em I8 de junho de 2018

Aprovado em I ${ }^{\circ}$ de abril de 2019

SILVA, Greize Alves da; BORGES, Patrícia Andréa. Presença vs ausência de traços de ruralidade no léxico tocantinense. Revista do Instituto de Estudos Brasileiros, Brasil, n. 72, p. 83-I05, abr. 2019.

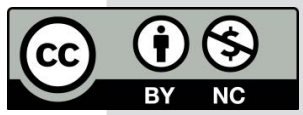

DOI: http://dx.doi.org/Io.II606/issn.23I6-90IX.voi72p83-I05

I Universidade Federal do Tocantins (UFT, Porto Nacional, TO, Brasil).

2 Universidade Estadual de Campinas (Unicamp, Campinas, SP, Brasil). 
Historiadores e sociólogos descrevem o Brasil, até o início do século XX, como essencialmente rural, herança das raízes colonizadorias iniciadas pelo litoral brasileiro. Mais recentemente, fenômenos como a Revolução Industrial e a globalização fizeram com que grandes centros urbanos nascessem e que populações, antes camponesas, procurassem esses destinos em busca de melhores oportunidades financeiras e sociais (ISQUERDO, 20I0).

No caso do Tocantins, especificamente, dois marcos assinalam o surgimento das cidades. O primeiro deles, no século XVIII, refere-se ao próprio fator de colonização do território: a busca por metais preciosos, fazendo com que populações procedentes do litoral se deslocassem para o interior do Brasil e iniciassem o ciclo extrativista na região (PALACÍN, 2008). O outro marco, porém, é mais recente e datado do século XX: a construção da Rodovia Belém-Brasília, ocasionando um deslocamento habitacional dos moradores das cidades mais tradicionais (antes arraiais de mineração) para habitar as cidades às margens da rodovia (AQUINO, 2004).

Em termos linguísticos, os fatores de urbanização que levam uma população, inicialmente rural, para morar em área urbana evidenciam uma nova dinâmica, por vezes, marcada pelo processo de perdas das marcas dialetais, de ordem fonética, lexical ou morfossintática, conceituadas como rurais. Segundo Isquerdo (20I0, p. 137),

Já o século XX foi marcado pelo êxodo rural e o fenômeno da globalização tem contribuído para acelerar imbricamentos entre formas eruditas, populares, tradicionais e modernas, em razão da facilidade de acesso aos meios de comunicação de massa. Nesse contexto, a língua portuguesa, distribuída espacialmente pelo território brasileiro, foi seguindo sua própria deriva e assumindo características neologizantes em algumas localidades e arcaizantes em outras.

Pesquisadores têm se dedicado atualmente à análise da presença ou da ausência de termos conceituados no mundo campesino (ROMANO; ISQUERDO, 2007; FREITAS; ISQUERDO, 2008), dado o universo das designações e, a depender da região pesquisada, a tendência ao desaparecimento ou à manutenção das formas procedentes desse universo. Comumente, esses estudos têm apontado alto índice de

3 Conhecida como Transbrasiliana ou BR-I53. 
não respostas ou de generalizações, principalmente por parte dos jovens, o que pode apontar que o léxico rural está em vias de desaparecimento.

Nesse sentido, propõe-se uma discussão a respeito das perdas ou das manutenções de marcas linguísticas conceituadas como agropastoris no universo do homem urbano tocantinense. Nesse recorte, especificamente, analisaram-se três questionamentos presentes no campo lexical "Frutas e atividades agropastoris", coletado pelo Atlas linguístico topodinâmico e topoestático do estado do Tocantins (ALiTTETO)4.

\section{O TOCANTINS RURAL E URBANO}

No que se refere especificamente ao antigo norte de Goiás, atual Tocantins, Salles (I992) estabelece comparativo entre três fases que constituíram a formação do território, que vão ao encontro da formação de outros muitos espaços brasileiros.

A história econômica de Goiás traça um quadro que parece comum a todas as épocas de conquista e povoamento: a primeira fase, de grandes feitos e lutas, de guerra aos gentios e procura de fontes de riqueza; a segunda, de exploração e formação de povoamentos incertos, muitas vezes provisórios; um terceiro momento, o trabalho agrícola, da fixação da propriedade rural e do labor artesanal, índice de futuros núcleos manufatureiros ou industriais. (SALLES, I992, p. I4).

As duas primeiras fases se estabelecem com a formação de territórios incertos, que, na grande maioria, estão ligados à exploração de metais preciosos, principalmente o ouro e, posteriormente, o cristal de rocha. No espaço Goiás-Tocantins, os arraiais nasceram nas regiões mais pobres do estado, no Vale do Rio Tocantins e de seus afluentes, como o rio Paranã, por exemplo.

Segundo Barbosa, Teixeira Neto e Gomes (2004, p. 65), a atividade mineratória impulsionou o nascimento das cidades, uma vez que os garimpos se transformavam em povoamentos urbanos. No entanto, o entendimento de "urbano" no período colonial merece certo relativismo, posto que consistia em espaços precários, com algumas construções, sedes administrativas e poucos serviços.

Comumente, "os arraiais-cidades" possuíam a seguinte configuração segregária: uma praça ao centro, uma igreja matriz e ruas tortuosas que convergiam nas praças. Próximo à igreja e à praça central, habitavam as famílias abastadas, enquanto os mais pobres viviam afastados dessas regiões, em casebres de taipa e de terra batida (BARBOSA; TEIXEIRA NETO; GOMES, 2004, p. 66).

O abastecimento das cidades era realizado por outro grupo, menos guarnecido-

4 O ALiTTETO teve por objetivo a coleta sistemática de dados linguísticos em I2 localidades tocantinenses. Os informantes foram estratificados por sexo (homens e mulheres), por idade - duas faixas etárias (I8 a 30 anos e 50 a 65), e por tipo de mobilidade (topoestáticos: informantes nascidos e estabelecidos nas cidades de pesquisa; topodinâmicos: informantes procedentes de migrações ou deslocamentos internos). Aos entrevistados foi aplicado questionário semiestruturado, com questões de ordem fonético-fonológica (QFF), semântico-lexical (QSM) e morfossintática (QMS). 
os agricultores e os criadores de gado - responsáveis pelo fornecimento de itens como: "carne, arroz, feijão, milho, mandioca, farinha e rapadura" (BARBOSA; TEIXEIRA NETO; GOMES, 2004, p. 69). De fato, as atividades agropastoris não impulsionaram o surgimento das cidades, mas foram as responsáveis por sua manutenção. Trata-se de uma fase de transição em que a economia já não se baseava nas atividades mineradoras como no período colonial.

No Goiás-Tocantins outro fator responsável pelo aparecimento de, pelo menos, $20 \%$ das cidades emergia justamente de grandes fazendas. Essas propriedades tinham por característica serem autossustentáveis em bens de primeira ordem. Normalmente, em torno da sede das fazendas, surgiam os vilarejos, com igrejas e com alguns comércios, tornando-se postos de paragem para os viajantes.

Barbosa, Teixeira Neto e Gomes (2004, p. 69) destacam que entre Goiás e Tocantins havia três regiões - Vale do Rio Tocantins, sudoeste goiano e vale do médio Araguaia - com destaque para as atividades agropastoris. $\mathrm{O}$ vale do Rio Tocantins foi a região mais antiga e a mais carente, mas que nos primórdios apresentou prosperidade em minas auríferas; localiza-se na microrregião de Dianópolis e engloba as cidades de Natividade, Arraias e Paranã, por exemplo, consideradas "cidades tradicionais" (AQUINO, 2004).

Paulatinamente, alguns fatores de urbanização fizeram que a região do vale do Rio Tocantins ficasse, de certa forma, menos povoada, dando origem a outras cidades. Aquino (2004) aponta que a construção da Rodovia Belém-Brasília, na década de I950, acarretou significativo crescimento das cidades em suas margens, uma vez que a população que antes habitava os limiares do rio Tocantins - em sua maioria, moradores da zona rural - migrou para as margens da estrada. Esse fator é apontado pelo pesquisador como preponderante no esvaziamento das cidades "tradicionais" $\mathrm{e}$ um aparente inchaço nos novos municípios ${ }^{6}$ ao longo da rodovia.

A título de exemplificação, com a utilização de dados do Censo do Instituto de Brasileiro de Geografia e Estatística (IBGE) de I99I e de 20I0, nota-se a significativa densidade demográfica das cidades próximas à BR-I53 em comparação com as localidades mais antigas, conforme quadros I e 2.

5 Atualmente, no Brasil, se trabalha com a noção de cidade estabelecida em I938, pelo Decreto 3II, em que toda sede de município pode ser considerada cidade. Veiga (2004) tece uma crítica a esse modelo, uma vez que essa noção deve englobar dois tipos de critérios: estruturais e funcionais. No critério estrutural, abarcam-se dados como número de habitantes, localização do espaço, densidade demográfica. O funcional, acolheria “os serviços indispensáveis à Urbe” (VEIGA, 2004, p. 28), tais como: escolas, farmácias, sede administrativa, corpo de bombeiros, polícia, locais para lazer, transporte público etc. A união desses dois critérios elevaria determinada vila, por exemplo, a receber o status de cidade.

6 Entende-se por município o espaço político composto por uma prefeitura e pela Câmara Municipal, que administra as áreas urbanas e rurais circunscritas a ele. 


\begin{tabular}{|l|c|c|c|c|c|c|}
\hline \multirow{2}{*}{ Cidades } & \multicolumn{2}{|c|}{ N. de habitantes } & \multicolumn{2}{c|}{ População rural } & \multicolumn{2}{c|}{ População urbana } \\
\cline { 2 - 7 } & $\mathbf{1 9 9 1}$ & $\mathbf{2 0 1 0}$ & $\mathbf{1 9 9 1}$ & $\mathbf{2 0 1 0}$ & $\mathbf{1 9 9 1}$ & $\mathbf{2 0 1 0}$ \\
\hline Dianópolis & 14.020 & 19.112 & 5.611 & 2.668 & $\mathbf{8 . 4 0 9}$ & 16.444 \\
\hline Arraias & 12.899 & 10.645 & 7.373 & 3.274 & 5.526 & 7.371 \\
\hline Peixe & 12.878 & 10.384 & 10.378 & 5.149 & 2.491 & 5.235 \\
\hline Paranã & 10.887 & 10.338 & 8.947 & 5.618 & 1.940 & 4.720 \\
\hline Natividade & 10.339 & $\mathbf{9 . 0 0 0}$ & 5.742 & 1.805 & 4.597 & 7.195 \\
\hline Total & $\mathbf{6 1 . 0 2 3}$ & $\mathbf{5 9 . 4 7 9}$ & $\mathbf{3 8 . 0 6 0}$ & $\mathbf{1 8 . 5 1 4}$ & $\mathbf{2 2 . 9 6 3}$ & $\mathbf{4 0 . 9 6 5}$ \\
\hline
\end{tabular}

Quadro I - População das cinco maiores cidades tradicionais do Tocantins.

Fonte: IBGE, Censo de I99I (AQUINO, 2004, p. 337); Censo de 2010

A microrregião de Dianópolis abriga, à exceção da cidade de Peixe, as quatro localidades conceituadas como tradicionais e descritas por Barbosa, Teixeira Neto e Gomes (2004, p. 69) como pertencentes ao Vale do Rio Tocantins. O Censo de I99I demonstra que a maior parte da população habitava as zonas rurais dos municípios elencados. Quase duas décadas depois, houve uma mudança demográfica no cenário: em 2010 apenas $31 \%$ ainda viviam no campo, o restante migrou da zona rural para a zona urbana dos municípios.

Destaca-se também o fato de que, se comparados os dois recortes censitários, a população total das cidades tradicionais diminuiu, possivelmente para se deslocar para cidades no entorno da BR-I53, fato corroborado pelo próximo quadro que evidencia as cinco maiores cidades na extensão da Belém-Brasília.

\begin{tabular}{|l|c|c|c|c|c|c|}
\hline \multirow{2}{*}{ Cidades } & \multicolumn{2}{|c|}{ N. de habitantes } & \multicolumn{2}{c|}{ População rural } & \multicolumn{2}{c|}{ População urbana } \\
\cline { 2 - 7 } & $\mathbf{1 9 9 1}$ & $\mathbf{2 0 1 0}$ & $\mathbf{1 9 9 1}$ & $\mathbf{2 0 1 0}$ & $\mathbf{1 9 9 1}$ & $\mathbf{2 0 1 0}$ \\
\hline Araguaina & 103.396 & 150.484 & 18.699 & 7.559 & 84.697 & 142.925 \\
\hline Gurupi & 56.741 & 76.755 & 4.232 & 1.755 & 52.509 & 75.000 \\
\hline Paraíso & 28.840 & 44.417 & 4.552 & 1.944 & 24.288 & 42.473 \\
\hline Colinas & 21.022 & 30.838 & 1.957 & 1.231 & 19.065 & 29.607 \\
\hline Guaraí & 20.829 & 23.200 & 6.249 & 2.072 & 14.580 & 21.128 \\
\hline Total & $\mathbf{2 3 0 . 8 2 8}$ & $\mathbf{3 2 5 . 6 9 4}$ & $\mathbf{3 5 . 6 8 9}$ & $\mathbf{1 4 . 5 6 1}$ & $\mathbf{1 9 5 . 1 3 9}$ & $\mathbf{3 1 1 . 1 3 3}$ \\
\hline
\end{tabular}

Quadro 2 - População das cinco maiores cidades do entorno da Rodovia BelémBrasília. Fonte: IBGE, Censo de I99I (Aquino, 2004, p. 337); Censo de 2010

Pelos dados fornecidos por Aquino (2004), a partir do Censo de I99I, nota-se que o número de habitantes das cidades próximas à rodovia, quando comparado ao das localidades tradicionais tocantinenses, praticamente quadruplicou. Quase 20 anos depois, no Censo de 20Io, esse número continuou a subir: Araguaína, por exemplo, na década de I990, apresentava I03.396 habitantes, chegando, em 2010, a mais de I50 mil. Em contrapartida, dentre as cinco cidades tradicionais (citadas no Quadro I), quatro delas apresentam decréscimo de sua população: a cidade de Arraias, no primeiro recenseamento, apresentava I2.899 habitantes e, duas décadas depois, computou Io.645.

Esse deslocamento populacional dentro do próprio estado, ou migração 
intraestadual, configura-se como característica dos habitantes. Estão, em sua maioria, atrelados à urbanização mais significativa de algumas microrregiões em detrimento de outras do chamado "progresso", principalmente das populações oriundas das comunidades mais tradicionais para os grandes centros. Segundo Aquino (2004, p. 342):

Não se deve esquecer que em tais processos está presente o fenômeno do êxodo rural, com acentuado esvaziamento do campo. As famílias que não emigram totalmente para as cidades, aos poucos vão "mandando" seus filhos em busca de estudos ou de empregos, enfim, em busca do sonhado conforto da cidade. A saída dos filhos transforma os lares sertanejos em verdadeiros refúgios de solidão.

Além dos refúgios de solicitação, essas localidades também se tornam refúgios linguísticos, pois a população envelhece e passa a ter pouco contato com a língua que se renova nos centros urbanos. Há uma espécie de cristalização da língua, já que o "não" contato com as renovações do léxico acaba por deixar a língua rural um tanto arcaizante.

\section{OS VEIOS DIALETAIS E O CONTINUUM RURAL VS URBANO}

Os fatores ocupacionais do que hoje se tornou o Tocantins se igualam ao entendimento dos princípios coloniais de todo o Brasil, principalmente sobre a formação das cidades, nas quais “Toda a estrutura de nossa sociedade colonial teve sua base fora dos meios urbanos [...]. Não foi a rigor uma civilização agrícola [...], foi uma civilização de raízes rurais [...]. As cidades são virtualmente, se não de fato, simples dependências delas" (HOLANDA, 2004, p. 73).

A indicação do autor ao estabelecer que o país, desde os primórdios, seguiu tendência agrária e suas cidades foram resultado direto dessa dinâmica, vai ao encontro da definição das áreas culturais brasileiras, com padrão rural-citadino, delineadas por Diégues Júnior (I980, p. 36) para o Brasil no princípio da colonização. Para ele, o principal responsável pela difusão de uma sociedade agrária, principalmente de linhagem aristocrática, foi o litoral nordestino - conceituado como o Nordeste Agrário, no qual são apontadas conexões com o processo colonizador português, iniciado pelas zonas litorâneas e, posteriormente, estendido para as áreas mais sertanejas, em busca de produtos para comércio, como o ouro, por exemplo.

Além da parte nordeste, como precursora de um movimento agrário/rural, há o indicativo de que em todas as outras regiões brasileiras o elemento campestre sempre foi o fator que impulsionou o crescimento, em maior ou menor escala, até o início do século XX. Para o autor, por exemplo, a configuração regional pode ser verificada em diferentes ordens em todas as regiões culturais.

No Mediterrâneo Pastoril, por exemplo, a economia era voltada, inicialmente, para os currais e, posteriormente, para as fazendas de criação. Na faixa conceituada como Amazônia, o domínio dos elementos floresta e água dá a tônica ao modo de vida regional, com costumes e tradições distintos dos das demais localidades, ocasionando 
uma terminologia peculiar à região, "enriquecida de termos adotados de outras atividades para a vida na água e na floresta” (DIÉGUES JÚNIOR, I980, p. 37).

A Região Centro-Oeste, não nascida necessariamente sob a égide pastoril, mas na exploração de metais preciosos, após a decadência das minas, dedicou-se a atividades de pecuária e agricultura, dentre outras ligadas ao ambiente campesino, movimento ainda substancial nos dias atuais.

Paralelo ao fato de sociólogos como Holanda (2004) e Diégues Júnior (I980) considerarem que o Brasil era, até o século XX, eminentemente camponês, censos do IBGE têm demonstrado que nas últimas décadas do século XX e início do XXI houve significativo declínio das populações em zonas rurais, que migraram para as áreas com maior concentração populacional. Estima-se que em 35 anos os camponeses passaram de mais 50\% para apenas I9\%. Os critérios adotados pelo Instituto consideram área urbanatodasede de municípios ou de distritos, independentemente do número de habitantes ou de atividade econômica. Nessa perspectiva, o Brasil abrigaria 5.507 municípios (BORTONI-RICARDO, 20II).

Os parâmetros supramencionados, adotados pelo IBGE para designar uma região como município urbano, têm recebido críticas por parte, principalmente, de pesquisadores como Veiga (2002), que estabelece que o critério mais fidedigno seria o da Organização de Cooperação e Desenvolvimento Econômico (OCDE). Segundo o órgão, são considerados municípios urbanos os que apresentam população de mais de 50 mil habitantes. Nesse parâmetro, o Brasil teria o total de 4II municípios (VEIGA, 2002), número bem inferior ao encontrado no IBGE (5.507).

No caso do Tocantins, o Instituto descreve I39 municípios oficiais, mas, se aplicados os critérios da OCDE, como sugerido por Veiga (2002), apenas Palmas, Araguaína, Gurupi, Porto Nacional e Paraíso do Tocantins poderiam ser considerados municípios, resultando em um declínio de aproximadamente $96,4 \%$ no quantitativo oficial.

Apesar dos critérios usados tanto pelo IBGE quanto pela OCDE, não há que se negar que nas últimas décadas houve um inchaço das grandes cidades e um esvaziamento de localidades tidas como zonas rurais, traduzido para Penna (2006) em processo de perda da identidade e desenraizamento desse migrante, normalmente pobre, que busca os grandes centros em busca de melhores oportunidades.

Comumente, o falante que outrora se viu compelido a sair de seu local de origem, por razões que vão desde "a impossibilidade de acesso à terra, a pobreza, a falta de recursos para enfrentar os problemas da natureza” (PENNA, 2006, p. 94), depara-se com uma nova realidade, principalmente dialetal, na qual precisa estabelecer novas relações sociais e, de certa forma, tentar adequar-se a esse novo panorama, transição nem sempre amena.

Nesse sentido, para Bortoni-Ricardo (20II p. 85), a localização de determinado migrante/falante, sua integração social e linguística, depende mais de sua rede de relações do que necessariamente de sua história social. Para a autora, redes sociais, como as encontradas em grandes cidades, exercem sobre os falantes alto grau de pressão linguística e reforçam padrões normativos, distanciando-se, por vezes, o falante de sua matriz de origem dialetal.

Nesse ambiente, o falante procedente do meio rural e atualmente projetado em um ambiente citadino vê-se submetido a adequar-se aos novos padrões linguísticos, 
de certa forma, exigidos pelo meio. Para Bortoni-Ricardo (20II, p. 92), essa nova comunidade de fala pode ser entendida como rurbana, ou seja, comunidade urbana "com preservação de seus antecedentes rurais" ou "populações rurais com razoável integração com a cultura urbana”.

Dialetologicamente, apenas nas últimas décadas, pesquisadores, com o aporte teórico da psicologia social e da antropologia, têm se dedicado à verificação dos continuum para descrever fatores de ordem linguística, ou seja, a variação estrutural e suas dicotomias, rural/urbana, por exemplo. Inicialmente, acreditava-se que o falar puro, típico de uma localidade estava nos meios rurais e, sob essa égide, nasceram os primeiros trabalhos linguísticos descritivos.

Como fator ilustrativo, para a dialetologia tradicional, os inquéritos linguísticos deveriam ser realizados junto a informantes que preenchessem as características descritas por Chambers e Trudgill (I994, p. 47) como NORM - nonmobile, older, rural, males -, entendido por Zágari (I998, p. 36) como HARAS - homem, adulto, rural, analfabeto, sedentário (baixa mobilidade demográfica).

Buscou-se esse tipo de informante uma vez que os linguistas, em essência, eram ligados a preceitos filológicos e tentavam coletar aspectos mais arcaizantes dos falares (dialetologia ciacrônica), por meio de indivíduos que não tivessem influência da zona urbana ou de qualquer outro meio de comunicação. Com essa metodologia, nasceram os primeiros atlas linguísticos.

No entanto, em função dos movimentos migratórios, do surgimento de novas vias de comunicação, sejam elas físicas ou digitais, dos contatos entre falantes de diferentes modalidades intervarietais, essa realidade e esse informante descrito por Chambers e Trudgill (I994, p. 47) não mais existem em essência. Nesse sentido, atualmente, faz-se imperativo considerar outras realidades sociais.

Altenhofen e Thun (20I6) estabelecem que em realidades plurais, como a de muitos estados brasileiros e, sobretudo, do Tocantins, cabe ao pesquisador observar quatro fatores: a) a condição de migração (estado migratório); b) o espaço da migração; c) a direcionalidade e o percurso da migração; d) a temporalidade da migração.

A “condição de migração" está diretamente ligada à mobilidade espacial do falante. É nesse contexto que o migrante, em contato com diferentes realidades, ressignifica sua língua, resultando, por vezes, na adoção de novas formas linguísticas extra matriz de origem (ALTENHOFEN; THUN, 20I6, p. 379-380). Destaca-se que esse fator atrela-se diretamente em sua aceitação ou não por nova comunidade linguística.

Para o "espaço da migração", os contínuos linguísticos/sociais são considerados, tais como: rural vs urbano, fronteiras vs interior, proximidade $v s$ distância de vias de comunicação para a descrição dialetal. Nesse último ponto, a análise de fatores como a Rodovia Belém-Brasília tem importante papel nas frentes migratórias para/no Tocantins. Localidades que estão às margens das rodovias têm tendência de se desenvolverem mais rapidamente que cidades periféricas, pois as relações sociais estabelecidas entre os moradores podem ser mais esparsas e abertas (BOTONI-RICARDO, 20II), ou seja, há tendência de o migrante manter vínculos com diferentes núcleos: família, emprego, igreja, dentre outros.

Em "direcionalidade e percurso da migração", verifica-se o caminho migratório realizado pelo falante, com o intuito de contrapor sua variante 
com trabalhos linguísticos realizados em seu local de origem. A partir desse percurso, tem-se a possibilidade de verificar os processos de mudança linguística em curso, a adoção de novas variantes e os desusos de formas linguísticas. Por fim, a "temporalidade da migração" diz respeito, entre outras direções, ao "tempo transcorrido de uma migração", assim como à "ordem de chegada" desse migrante em território escolhido (ALTENHOFEN; THUN, 20I6, p. 39I). O conhecimento desses fatores leva ao entendimento de mecanismos de manutenção ou de adoção de uma nova variedade linguística por parte do migrante.

Ressalta-se que gerações mais velhas tendem à manutenção de sua variante de origem, rural, por exemplo, enquanto os mais jovens inclinam-se à adoção da norma local, a depender do "tempo" e da quantidade "de contatos" que esses falantes estabelecem (MARGOTTI, 20I6, p. 368), ou seja, se a rede de contatos é mais densa ou menos densa, o que pode ser traduzido no esquema a seguir:

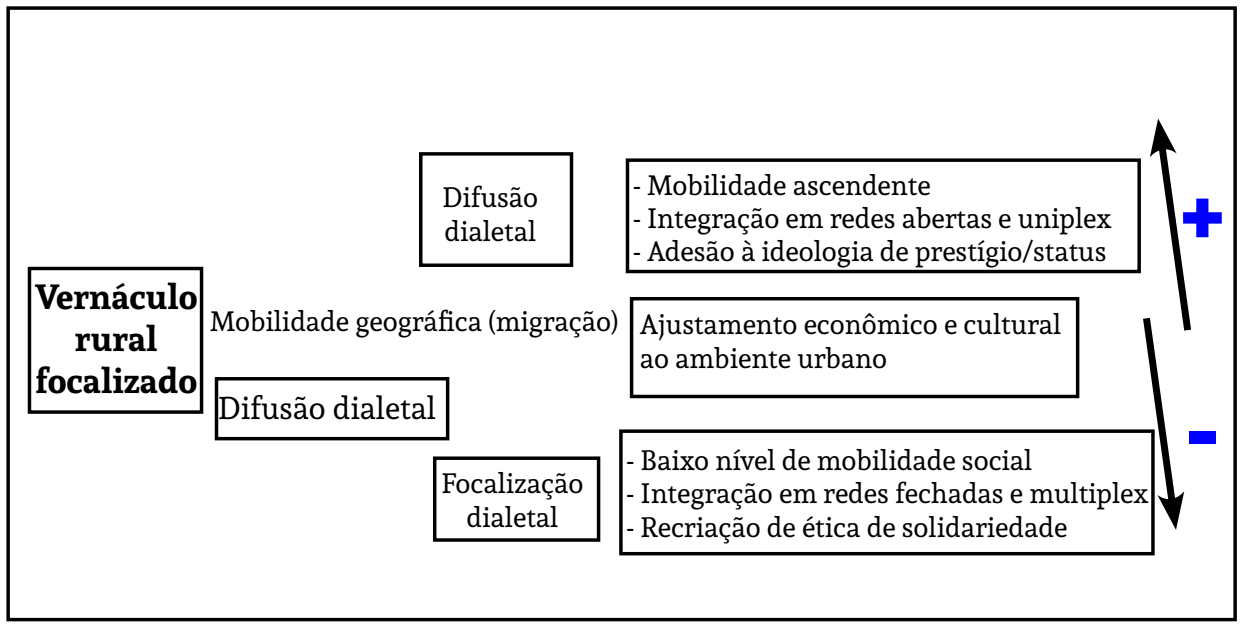

Figura I - Migração rural/urbana - focalização e difusão dialetal. Fonte: Bortoni-Ricardo (20II, p. I24), adaptado

O esquema fornecido por Bortoni-Ricardo (20II, p. I24) apresenta o falante procedente do meio rural, após sua mobilidade espacial, frente a duas situações. A primeira delas atrela-se ao movimento socioeconômico desse antigo camponês em sentido ascendente, ou seja, se esse falante encontra nos grandes centros as melhores oportunidades de vida e de trabalho, e à integração social. Nessa situação, o migrante tende a adquirir redes mais abertas e há tentativas de se adequar aos padrões de prestígio, por exemplo.

Situação oposta é verificada quando o falante não se ajusta econômica ou culturalmente ao ambiente citadino e encontra nessa escala pouca mobilidade social. $\mathrm{O}$ movimento desse migrante é mais centrípeto, pois busca nos seus semelhantes, parentes e amigos procedentes do mesmo meio suas relações sociais. Nesse panorama, há menor tendência à adoção de padrões de prestígio, e o migrante mantém seu falar de origem.

Em comunidades rurbanas, caso do Tocantins, por exemplo, nota-se que, em situações de entrevista linguística, verifica-se duplo processo: ora o informante 
se acomoda dialetalmente ao novo ambiente e apresenta as variantes típicas do ambiente citadino (acomodação dialetal), ora apresenta as marcas rurais de sua região de procedência, como pode ser evidenciado no próximo tópico.

\section{Traços do léXico RURAL No TOCANTINS}

Para a verificação dos padrões linguísticos, mais ou menos rurais dos informantes inquiridos pelo ALiTTETO, selecionaram-se três questionamentos presentes no campo semântico "Frutas e atividades agropastoris", aplicados aos 96 informantes, vinculados ao universo urbano em I2 localidades tocantinenses. As perguntas são: 28 - ponta roxa do cacho da banana; 38 - objeto de vime, de taquara, de cipó trançado, usado para levar batatas, mandiocas no lombo do cavalo ou do burro; 40 - objeto de couro, com tampa, para levar farinha no lombo do cavalo ou do burro.

Cabe acrescentar que se considerou a não resposta do informante, ou seja, a ausência responsiva no momento do inquérito, como um tipo de resposta, uma vez que esse desconhecimento do referente solicitado na questão fornece indicativos da manutenção ou das perdas de formas conceituadas como rurais.

Para as variantes obtidas mediante a indagação 28 - Como se chama a ponta roxa do cacho da banana? -, coletaram-se 87 respostas, distribuídas em II unidades lexicais; não souberam responder 27 informantes, em sua maioria, jovens incluídos na primeira faixa etária I (I8 a 30 anos). Os resultados com as variantes, número de ocorrências e percentuais estão dispostos no Quadro 3.

\begin{tabular}{|l|c|c|c|c|c|}
\hline \multicolumn{1}{|c|}{ Variante } & N. de ocorrências & \% & Variante & N. de ocorrências & $\%$ \\
\hline Mangará & 28 & $24,6 \%$ & Fio & 2 & $1,8 \%$ \\
\hline Não resposta & 27 & $23,7 \%$ & Cacho & 1 & $0,9 \%$ \\
\hline Umbigo & 19 & $16,7 \%$ & Figa & 1 & $0,9 \%$ \\
\hline Coração & 14 & $12,3 \%$ & Olho & 1 & $0,9 \%$ \\
\hline Buzo & 10 & $8,8 \%$ & Pendão & 1 & $0,9 \%$ \\
\hline Flor (da bananeira) & 9 & $7,9 \%$ & Penca & 1 & $0,9 \%$ \\
\hline & $\mathbf{8 7}$ \\
\hline
\end{tabular}

Quadro 3- Designações para ponta roxa do cacho da bananeira, e respectivos números de ocorrências e percentuais. Fonte: Silva, 2018

Nota-se que a variante mais recorrente é mangará7, dicionarizado como tupinismo

7 O termo é fornecido por Houaiss (2009) como tupinismo e regionalismo do Nordeste brasileiro, com datação que remonta a I584. Entretanto, foi registrado como proeminente nos dados de Guedes (20I2), no estado do Pará, e, na carta Lo7 do Atlas linguístico do Brasil (CARDOSO et al., 2014), mangará é dominante tanto nas capitais dos estados do Norte quanto nas nordestinas: Fortaleza, Natal e João Pessoa; em menor escala, em São Luís e Teresina. O vocábulo, portanto, não se configuraria apenas como regionalismo nordestino. Ainda no corpus de Guedes (20I2), a hegemonia de mangará perde sua força no ponto limítrofe entre Pará e Tocantins, onde concorre com umbigo, segunda variante em número percentual em nossos dados, mas não lexicalizada em Houaiss (2009) para o item em questão. 
por Houaiss (2009), com datação de I584. A diatopia do termo se encontra estendida para quase todo o estado do Tocantins, com exceção da lateral sudeste.

O segundo percentual obtido se refere ao índice de não respostas para a pergunta em questão, 23,7\%. As ausências responsivas ocorrem mais intensamente nas cidades às margens do rio Tocantins e da BR-I53, sem apresentar distinção entre cidades mais velhas ou mais recentes. Nota-se que essa ausência de respostas recorre principalmente nos informantes da primeira faixa etária, entre I8 e 30 anos.

Umbigo, terceiro percentual de ocorrências, aparece em quase todo o Tocantins, com exceção da lateral nordeste, predominantemente proferido pela faixa etária II (entre 50 e 65 anos). Está agrupado em posição oposta a mangará e muito incidente nas cidades de Natividade e de Paranã (sudeste), cidades tradicionais, antigos arraiais de mineração.

Por seu turno, o item lexical coração $0^{8}$ possui distribuição no extremo norte e no extremo sul do estado, realizando-se em todos os limites estaduais. É mais incidente na faixa etária I, apesar de ocorrer também na faixa etária II.

Quanto a $b u^{9} 0^{9}$, quarto item, registrou-se na área conhecida como falar baiano (ver NASCENTES, 20I2), região oposta a mangará, apresentando uma forma isoléxica nesse espaço, ou seja, indica a formação de uma região dialetal de uso quase exclusivo de uma forma linguística em detrimento de outra.

A lexia flor (da bananeira) ${ }^{\mathrm{Io}}$, com nove ocorrências, encontra-se disseminada pelo território de pesquisa, com exceção dos limites fronteiriços com o Maranhão. Inicialmente, acreditou-se que o conceito se tratava de uma generalização fornecida pelos informantes, mas o item foi coletado pelo Atlas linguístico do Brasil em diferentes regiões brasileiras (CARDOSO et al., 20I4). Sua ocorrência dá-se, principalmente, nas mulheres jovens.

Com poucas ocorrências tem-se fio, cacho, figa, olho, pendão e penca, designações genéricas, comuns, e dicionarizadas com outras acepções, fornecidas pelo fato de o informante desconhecer o referente. Essas designações gerais foram coletadas, em

8 Consta em Houaiss (2009) como regionalismo do Nordeste e como variante para mangará, com datação de I278. No ALiB, coração foi expresso pelos informantes das três capitais sulistas e, com menor presença, no Centro-Oeste (Goiânia e Mato Grosso) e Nordeste (Salvador e Aracaju) (CARDOSO et al., 20I4, p. I73, carta Lo7). Dessa forma, possivelmente seja uma variante irradiada do Centro-Oeste ou do Nordeste para o Tocantins.

9 No ALS I, buzo concorre com buzina; na Bahia, encontra-se como buzo, buza e buzina em todo o território (ROSSI et al., I963). Seu registro não consta dos dados de Guedes (20I2), no Pará, nem nas capitais do Norte analisadas pelo ALiB, mas foi notada em Maceió e em Aracaju (CARDOSO et al., 20I4). Dessa forma, possivelmente se trata de uma variante nordestina que adentrou o Tocantins e, dada a localização da variante, foi introduzida via Bahia. O termo não é registrado por Aulete (I986) nem por Houaiss (2009) como inflorescência da banana, mas, dentre as acepções encontradas e dadas as características do referente, podemos crer que se trata de uma alusão à aparência física do item, que remonta ao instrumento buzina, em sua forma antiga ovalada, uma das variantes coletadas em Sergipe (ALS) e Bahia (APFB).

Io No Atlas linguístico do Brasil (CARDOSO et al. 20I4), a partir do cartograma Lo7, flor é mais frequente no Rio Grande do Sul e São Paulo, com baixos índices em Vitória e no Recife. Na parte ocidental do Brasil, aparece em Cuiabá, Porto Velho, Rio Branco e Macapá. A situação averiguada, em confronto com nossos dados, pode evidenciar influências migratórias procedentes do Sul/Sudeste em direção ao Norte/Nordeste. 
sua maioria, junto aos homens (penca, olho, cacho e fio - faixa etária I; pendão e figa faixa etária II), como pode ser verificado no Gráfico I, que apresenta as variantes por ordem decrescente quanto ao percentual de ocorrências de cada forma.

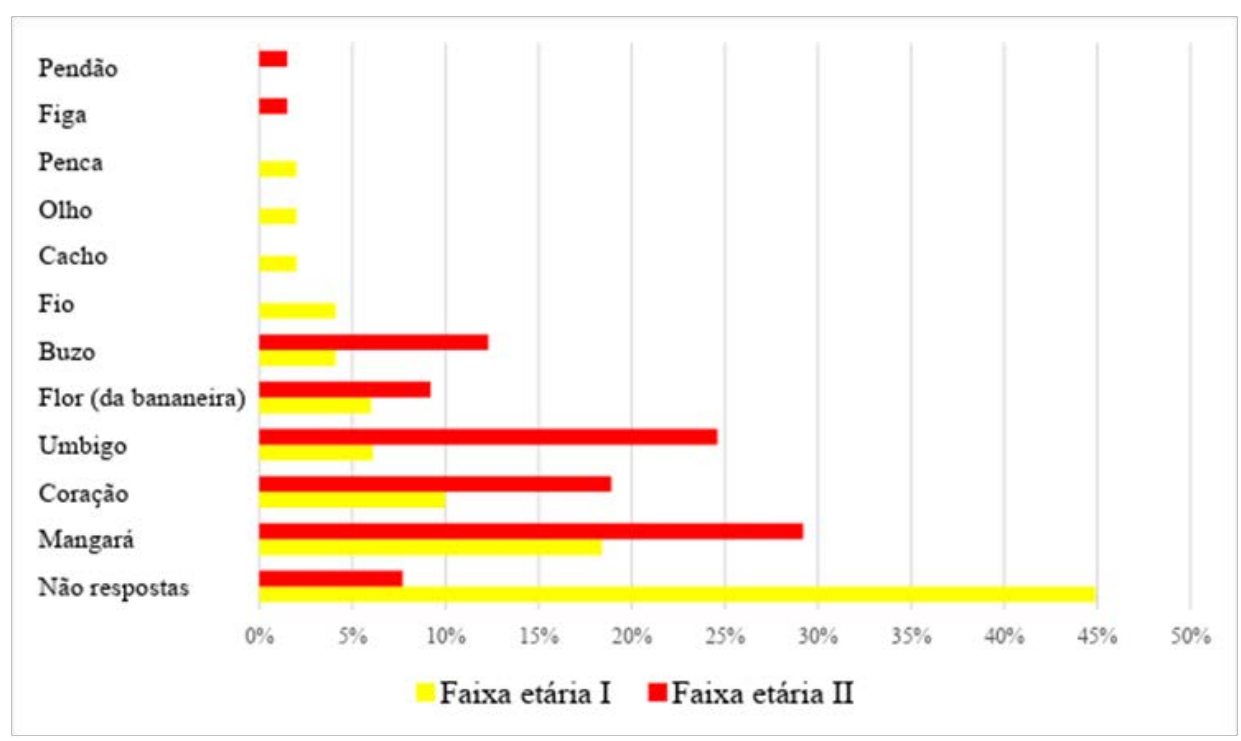

Gráfico I - Distribuição das variantes por faixa etária (QSL 028). Fonte: Silva, 2018

Pelo recorte geracional (informantes entre I8 e 30 anos e entre 50 e 65), o maior percentual ocorrido nos informantes da faixa etária I se atrela as não respostas, ou seja, à inexistência de conhecimento sobre o referente solicitado, possivelmente por não fazer parte do universo linguístico do informante mais jovem.

A esse respeito, Ziamandanis (I999, p. 656) indica que, no momento do inquérito, o silêncio por parte do entrevistado pode ser interpretado de duas formas. No primeiro caso significa que o informante desconhece mentalmente o vocábulo solicitado ou, se conhece, está impossibilitado de relembrar o nome atribuído por este fazer parte de um acervo mental secundário. Por outro lado, a autora indica que a ausência de resposta pode indicar cansaço, por parte do entrevistado, ocasionado pela duração da entrevista.

O primeiro indicativo fornecido pela autora vai ao encontro dos postulados sobre a ausência de vocábulos mais restritos ao universo rural, fato corroborado pelos dados presentes no Gráfico I, com os comparativos entre as variantes produzidas pelas faixas etárias I e pela II. Enquanto, entre os jovens, 44,9\% alegam desconhecer vocábulos que designam a inflorescência da bananeira, entre os mais velhos apenas $7,7 \%$ não responderam. Além disso, há abundante citação de termos genéricos por parte dos mais jovens, enquanto os mais velhos tendem a concentrar suas respostas em poucos itens, tais como mangará, coração e umbigo, por exemplo.

A Figura I evidencia a distribuição em termos diatópicos e diageracionais das variantes obtidas. As não respostas, marcadas em verde-claro, ocorrem predominantemente nos primeiros círculos que representam os informantes jovens. 
Nota-se que em Porto Nacional, por exemplo, nenhum dos informantes dessa faixa etária soube responder ao questionamento.

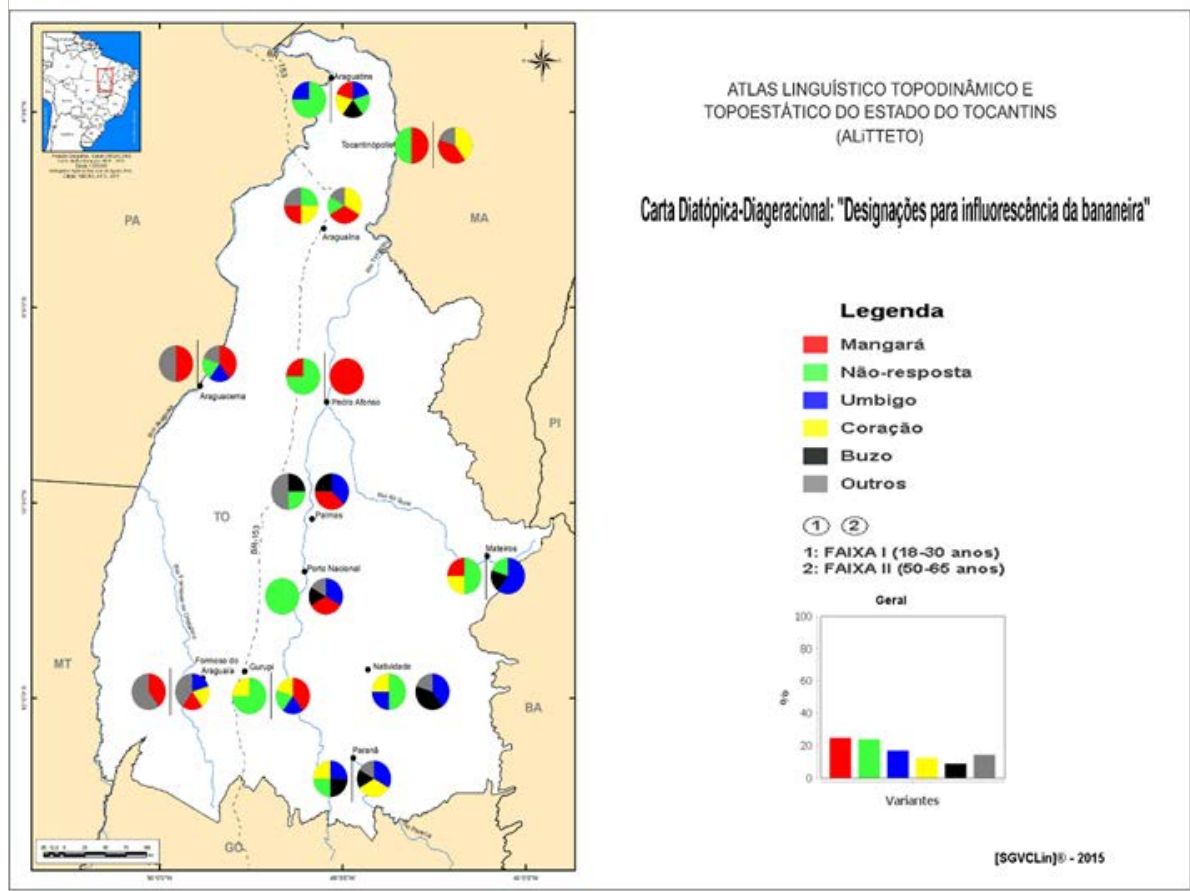

Figura I - Cartograma diatópico-diageracional para inflorescência da bananeira. Fonte: Silva, 20I8

A carta linguística demonstra mais claramente as ausências responsivas na primeira faixa etária e fornece indícios de que algumas regiões apresentam maior desconhecimento do referente, caso de Gurupi, Porto Nacional, Pedro Afonso e Araguatins, o que pode ser ocasionado, também, pela inexistência desse tipo de cultivo.

A lateral oeste da BR-I53 apresenta pouca incidência de desconhecimento do referente. Em Formoso do Araguaia, por exemplo, todos os informantes conhecem a inflorescência da bananeira; tal evidência se fundamenta no fato de nessa região haver polos agrários, fazendo com que os falantes dessa localidade mantenham contato com ambientes e culturas mais rurais.

Em suma, em um universo de 48 informantes jovens entrevistados, quase a metade desconhece o item solicitado no questionamento; entre os mais velhos, por outro lado, apenas sete não responderam. Além disso, na coleta de II formas lexicais para designar a inflorescência da bananeira, pelo menos seis delas (fio, cacho, figa, olho, pendão e penca) são respostas genéricas, fornecidas predominantemente pelos jovens.

No universo desse questionamento, em específico, há tendência à não adoção de formas pertencentes ao ambiente rural, principalmente pela faixa etária dos mais jovens, o que pode indicar que essas formas estão em vias de desaparecimento.

Ainda nesse mesmo entendimento analítico, para a questão 38 - Como se chamam 
aqueles objetos de vime, de taquara, de cipó trançado, para levar batatas, mandioca, no lombo do cavalo ou do burro -, coletaram-se I2 formas distintas, fornecidas em um universo de 124 respostas. O Quadro 4 apresenta as variantes, o número de ocorrências e os percentuais respectivos.

\begin{tabular}{|l|c|c|l|c|c|}
\hline \multicolumn{1}{|c|}{ Variante } & N. de ocorrências & $\%$ & \multicolumn{1}{c|}{ Variante } & N. de ocorrências & $\%$ \\
\hline Jacá & 49 & $39,5 \%$ & Capanga/bolsa/embornal & 3 & $2,4 \%$ \\
\hline Balaio & 22 & $17,7 \%$ & Alforje & 2 & $1,6 \%$ \\
\hline Cesto/cesta & 19 & $15,3 \%$ & Garajau & 2 & $1,6 \%$ \\
\hline Cofo & 9 & $7,3 \%$ & Cocho & 1 & $0,8 \%$ \\
\hline Caçuá & 6 & $4,8 \%$ & Chocononto & 1 & $0,8 \%$ \\
\hline Não resposta & 5 & $4,0 \%$ & Arupemba & 1 & $0,8 \%$ \\
\hline Pacará & 4 & $3,2 \%$ & & & \\
\hline
\end{tabular}

Quadro 4-Designações para os objetos feitos de fibra natural, colocados sobre o lombo do cavalo ou do burro. Fonte: elaboração da autora com base nos dados de Silva, 2018

Considera-se que as duas primeiras variantes, jacá e balaio, descrevem o item em questão a partir da dicionarização de ambos: "tipo de cesto feito a partir de fibras naturais” (HOUAISS, 2009), ou seja, os maiores índices de citações por parte dos informantes do ALiTTETO denotam o referente da questão. Jacá ${ }^{I I}$ se distribui por todos os pontos de inquérito, mais intensamente na fração centro-norte, enquanto na porção centro-sul do Tocantins, irradiando para as divisas com Bahia, Piauí e Maranhão, na localidade de Mateiros, há maior concentração de balaio ${ }^{\text {I2 }}$.

Em contrapartida, a terceira variante mais produtiva, cesto/cesta, entendida pelos dicionaristas como um tipo geral de utensílio (AULETE, I986), que serve para transportar "coisas", é um item genérico, não necessariamente usado no transporte de mantimentos no lombo do animal. A distribuição do item foi uniforme nas I2 cidades, evidenciando-se predominantemente no falar dos jovens.

Em menor escala estão os itens $\operatorname{cofo}^{\mathrm{I3}}$, disperso pelo território, tanto em localidades mais recentes quanto em cidades mais antigas, e caçuá ${ }^{I 4}$ registrado por seis informantes e coletado sempre nos pontos de divisa estaduais. Quanto às não respostas, no total de cinco (4\%), verifica-se que todas são oriundas das localidades a partir do centro estadual em direção ao sul do Tocantins.

Os termos do agrupamento capanga/bolsa/embornal, realizado a partir do traço

II Procede do tupi aiacá, registrado em I698 (AULETE, I986), com indicação de que sua produção é feita com a fibra natural da taquara (HOUAISS, 2009).

I2 Tem etimologia desconhecida, mas é datado em I524.

I3 Aulete (I986) apresenta-o como objeto utilizado por pescadores e sua etimologia remete a cofinho, proveniente do Minho (Portugal), com datação do século XIV.

I4 Variante de origem controversa, possivelmente africana, de I889 (HOUAISS, 2009), foi registrada por seis informantes e coletada sempre nos pontos de divisa estaduais, não ocorrendo apenas no limite entre Goiás e Tocantins. Consultando outros atlas estaduais, verificamos que, segundo Guedes (20I2), é a variante mais produtiva no Pará, concorrendo com panero. Nos dados do Atlas Linguístico do Amazonas (CRUZ, 2004, [Carta 94]), foi pouco recorrente. 
semântico comum entre as formas, estão todos dicionarizados como um tipo de bolsa usada para carregar mantimentos, independentemente do material usado na confecção. Ocorreram de forma esparsa no espaço de pesquisa: duas citações no norte e outra na capital Palmas.

Na porção centro-leste, foram registrados, com pouca representatividade, os itens pacará (Porto Nacional e Mateiros), garajau (Palmas e Natividade) e alforje (Palmas e Paranã) ${ }^{\mathrm{IS}}$. As incidências únicas - arupemba, cocho, chocononto - ocorrem no sul-sudeste do Tocantins. Nenhum dos itens está lexicalizado nos dicionários consultados.

No recorte por faixa etária, conforme Gráfico 2, diferentemente do que ocorreu na questão QSL 28, há pouca ausência de respostas em ambos os grupos, apesar do predomínio desse fato nos mais jovens.

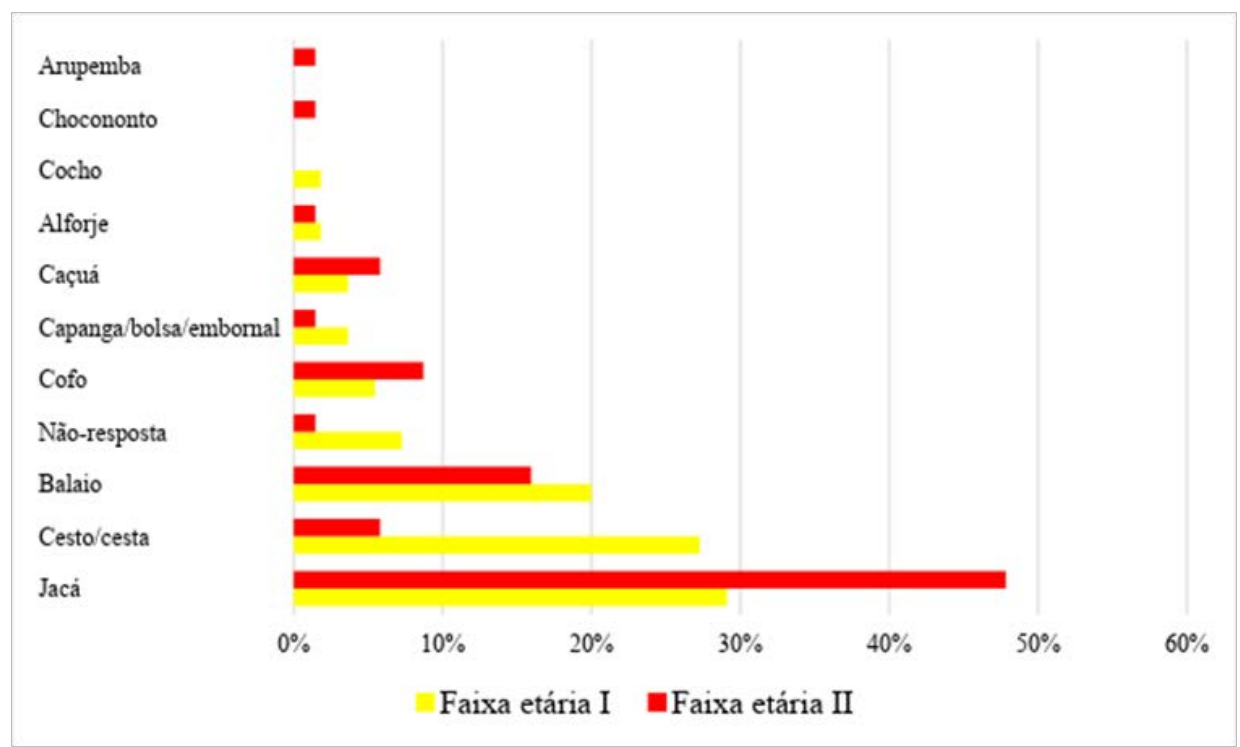

Gráfico 2 - Distribuição das variantes por faixa etária (QSL 38). Fonte: Silva, 2018

Entre todas as variáveis predomina jacá, com maior índice na fala dos informantes idosos. Por outro lado, a segunda variante no núcleo jovem refere-se a cesto/cesta, designação, possivelmente generalista, enquanto, entre os mais velhos, aufere-se balaio. Destaca-se que em ambas as faixas etárias, não apenas nos jovens, foram abundantes as citações de ordem generalista, normalmente, auferida por apenas um informante cada.

Quanto ao índice de não respostas, apesar de haver predomínio nos falantes da faixa etária I, ao todo, em ambos os grupos, esse fator não se mostrou relevante nessa questão, conforme cartograma que ilustra as variantes mais recorrentes e a ausência de resposta.

I5 Os dois primeiros, etimologicamente, são apresentados como tupinismos, de I763 e I899, respectivamente, e são descritos como tipos de cestos feitos com fibras naturais. Alforje, por sua vez, tem origem no árabe al-khurj, "saco que se leva ao lado, na sela”, apresentando a datação mais antiga dos três: п162 (HOUAISS, 2009). 


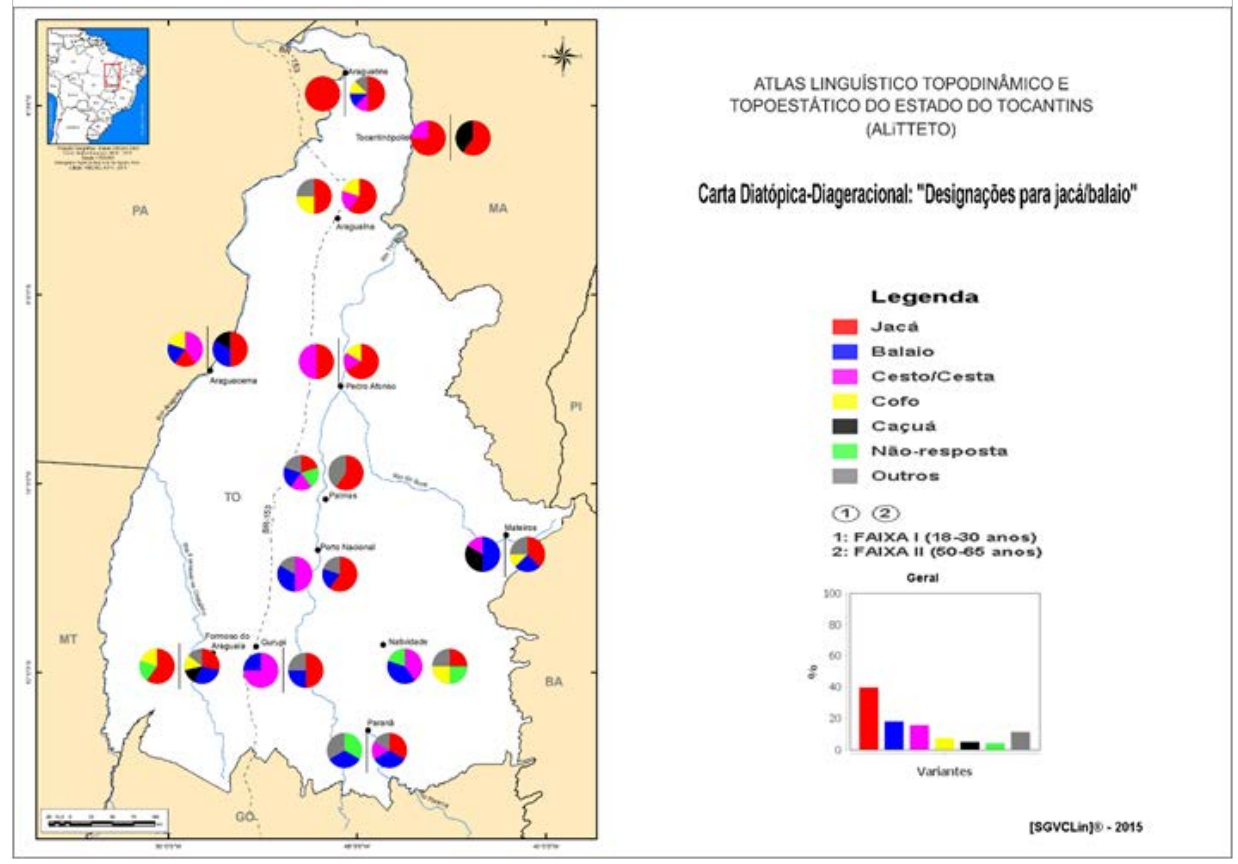

Figura 2 - Cartograma diatópico-diageracional. Fonte: Silva, 20I8

A diatopia evidenciada no cartograma apresenta maior índice de não respostas a partir do centro-sul estadual. Observa-se que, na metade norte tocantinense, todos os informantes conhecem o item solicitado e, na maioria das vezes, citaram jacá ou cesto/cesta. Quanto à metade sul, evidencia-se maior ecletismo nas respostas, não sendo possível traçar isoléxicas.

Ao confrontar os resultados da QSL 28 com os da QSL 38, no que se refere às não respostas, verifica-se que, no segundo agrupamento, os informantes, tanto jovens como idosos, parecem conhecer os referentes. Mesmo os informantes da primeira faixa etária, embora tenham citado termos generalistas como cesto/cesta, parecem pertencer ao universo agropastoril pesquisado.

Para a última questão desse campo semântico, que diz respeito ao questionamento 040 - Como se chamam os objetos de couro, com tampa, para levar farinha no lombo do cavalo ou do burro? -, recolheu-se o total de I20 respostas, distribuídas entre I 5 formas; onze informantes não souberam responder. O Quadro 5 mostra as variantes, o total de ocorrências e os percentuais respectivos. 


\begin{tabular}{|l|c|c|l|c|c|}
\hline \multicolumn{1}{|c|}{ Variante } & N. de ocorrências & $\%$ & Variante & N. de ocorrências & $\%$ \\
\hline Alforje & 21 & $17,5 \%$ & Caixote & 5 & $4,2 \%$ \\
\hline Buraca/bruaca & 21 & $17,5 \%$ & Cesto/cesta & 3 & $2,5 \%$ \\
\hline Caçuá & 14 & $11,7 \%$ & Embornal & 2 & $1,7 \%$ \\
\hline Jacá & 11 & $9,2 \%$ & Gibão & 1 & $1,7 \%$ \\
\hline Mala/maleta (de couro) & 11 & $9,2 \%$ & Mocó & 1 & $0,8 \%$ \\
\hline Não resposta & 11 & $9,2 \%$ & Garajau & 1 & $0,8 \%$ \\
\hline Baú & 9 & $7,5 \%$ & Sucuntum & 1 & $0,8 \%$ \\
\hline Bolsa & 6 & $5,0 \%$ & Surrão & 1 & $0,8 \%$ \\
\hline & 120 & & \\
\hline
\end{tabular}

Quadro 5-Designações para os objetos de couro, utilizados para levar farinha, no lombo do cavalo ou do burro. Fonte: Silva, 20I8

Alforje $^{\mathrm{I} 6}$, item predominante, assim como buraca/bruaca, possui distribuição constante em todo o Tocantins, com exceção das cidades de Araguacema e de Natividade. Nesse caso, dada a quantidade significativa de citações para designar os objetos, assim como as abonações fornecidas pelos informantes, considera-se a presente resposta como válida para o referente em análise, mesmo tendo em vista que alforje nomeia outros objetos, tais como evidenciados nas análises da QSL 38.

Esse fato também foi verificado por Isquerdo (20I0) em trabalho com os dados coletados nas capitais brasileiras. Segundo a autora, o desconhecimento do informante em relação ao item faz com que ele aluda a outros semas que aproximam as designações em termos semânticos (formato, utilidade, material com que é confeccionado), como baú, bolsa, alforje, embornal, mala, malote, mochila.

Buraca/bruaca ${ }^{17}$ ocorrem na porção sudeste e predominam nas cidades históricas de Porto Nacional, Natividade e Paranã, localidades que abrigaram grande contingente de portugueses e escravos em decorrência das minas de ouro e outros metais; essas variantes irradiam para as cidades limítrofes a Palmas, Mateiros e Gurupi. Isquerdo (20Io) acrescenta que o termo bruaca atrela-se a um universo rural, o que pode indicar que, nessas localidades, ainda há traços lexicais de colonização ${ }^{18}$. Buraca/bruaca formam consistente isoléxica na parte sudeste do Tocantins.

O terceiro item foi caçuá, e sua validação e inserção na análise deu-se em função da quantidade de respostas e explicações por parte dos sujeitos de pesquisa, pois, segundo os dicionários, esse objeto é comumente fabricado com fibras naturais e não com couro, como solicitado na pergunta, assim como alforje. O registro dele não

I6 Segundo Houaiss (2009), trata-se de um arabismo (al-khurj), com datação de II62, mas não há menção no dicionário se esse item é fabricado com couro.

I7 Os dois itens têm origem atribuída ao espanholismo burjaca, "bolsa de mendigo ou peregrino", de I836.

Em Houaiss (2009), nessa entrada há a remissão a bruaca e designativo para saco ou mala rústica. Buraca também foi registrada, de forma predominante, no trabalho de Augusto (20I2), em Goiás, denotando assim que a procedência da variante seja do citado estado, pois as cidades de registro dessa variante são próximas dos limites estaduais Goiás-Tocantins, sobretudo Paranã.

I8 Quanto à diatopia encontrada em outros trabalhos, em Marins (20I4), na Região Centro-Oeste, predomina bruaca, enquanto a forma buraca constitui uma área de isoléxica em Goiás, nas proximidades com o Tocantins. 
ocorre justamente nas cidades da fração sudeste, onde predominam buraca e bruaca. Caçuá irradia da parte sudoeste, onde estão as localidades mais novas, surgidas ao longo da BR-I53, e sobe em sentido norte; em Araguatins, por exemplo, essa forma apresentou índice de $42 \%$.

Conforme destacado, caçuá ${ }^{19}$ distribui-se por todo o norte, pela parte central e pelo sudoeste; concorre com buraca e bruaca em Gurupi e Mateiros, que podemos considerar como zonas de transição dessa variante, enquanto, na parte central e sudeste, predomina buraca e bruaca. Outro aspecto que pode ser levantado permeia o fato de que a citação de caçuá indica certo desconhecimento dos informantes dessas localidades em relação ao referente - bolsa de couro -, ou seja, as localidades mais recentes exibem traços menos rurais do que os apresentados no sudeste do Tocantins, por exemplo.

A forma jacá, também identificada na questão 38, ocorre, assim como caçuá, nas cidades do entorno da rodovia Transbrasiliana (BR-I53) e do rio Tocantins. Apresenta-se com maior percentual na fala das mulheres procedentes de migrações (topodinâmicas), podendo denotar tratar-se de variante nordestina presente no território.

Com índice pouco superior a I0\%, há os termos genéricos mala/maleta de couro, auferidos no território, com exceção de Natividade, Paranã, Gurupi e Araguaína. Designam, de forma ampla, os utensílios para guardar coisas, com a especificação de serem fabricadas com couro.

Onze informantes não souberam responder ao questionamento (9,2\%), número menor se comparado ao índice de desconhecimento do referente na região centro-oeste, por exemplo, de aproximadamente $20 \%$ (ISQUERDO, 20Io), indicando que o Tocantins apresenta indícios de um português com traços de ruralidade nesse questionamento.

Ainda foram registradas, em baixa escala, variantes como baú, bolsa, caixote, cesto e embornal, possivelmente provenientes do desconhecimento do informante em relação ao objeto feito de pele bovina.

Cada uma das variantes gibão, mocó, garajau, surrão $0^{20}$ e sucuntum obteve apenas um registro. Os únicos termos lexicalizados que se aproximam parcialmente do referente são garajau e surrão: o primeiro indicando um tipo de cesto, não necessariamente de couro; o segundo, um tipo de sacola de couro usada por pastores (HOUAISS, 2009).

Isquerdo (20Io, p. 8) destaca que a citação de formas mais gerais ou que nomeiam outro referente se atrela a dois indícios: "o desuso do signo em decorrência do desaparecimento do referente e a seleção interna da língua que impõe a supremacia de um signo ao outro, normalmente a variante de maior prestígio". Nesses dados, assim como nos da autora, o desconhecimento do referente se vincula ao primeiro indicativo: a não utilização do objeto em cidades mais jovens e industrializadas no Tocantins, o que leva o informante a formular nomes mais próximos da sua realidade.

I9 Dada a divisa com Goiás e a ocorrência desse item em Augusto (20I2) e Marins (20I4), podemos deduzir que buraca e bruaca são termos oriundos do Centro-Oeste, enquanto caçuá, localizado nas cidades ao longo e proximidades da BR-I53, pode ser procedente das migrações Norte/Nordeste, mesmo ocorrendo, em sua maioria, entre os informantes topoestáticos.

20 Variante também auferida nos dados de Marins (20I4), nas localidades do Centro-Oeste: Barra do Garças (MT), Poxoréu (MS) e Corumbá (MS). 
Ao analisar as citações lexicais por recorte etário, evidencia-se que a faixa etária I foi responsável por I5\% das não respostas, enquanto na faixa II o índice não chega a 4\%, conforme se verifica no Gráfico 3, que apresenta a disposição das variantes, das menos incidentes para as mais incidentes, iniciadas pelas formas encontradas exclusivamente na segunda faixa etária (50 a 65 anos).

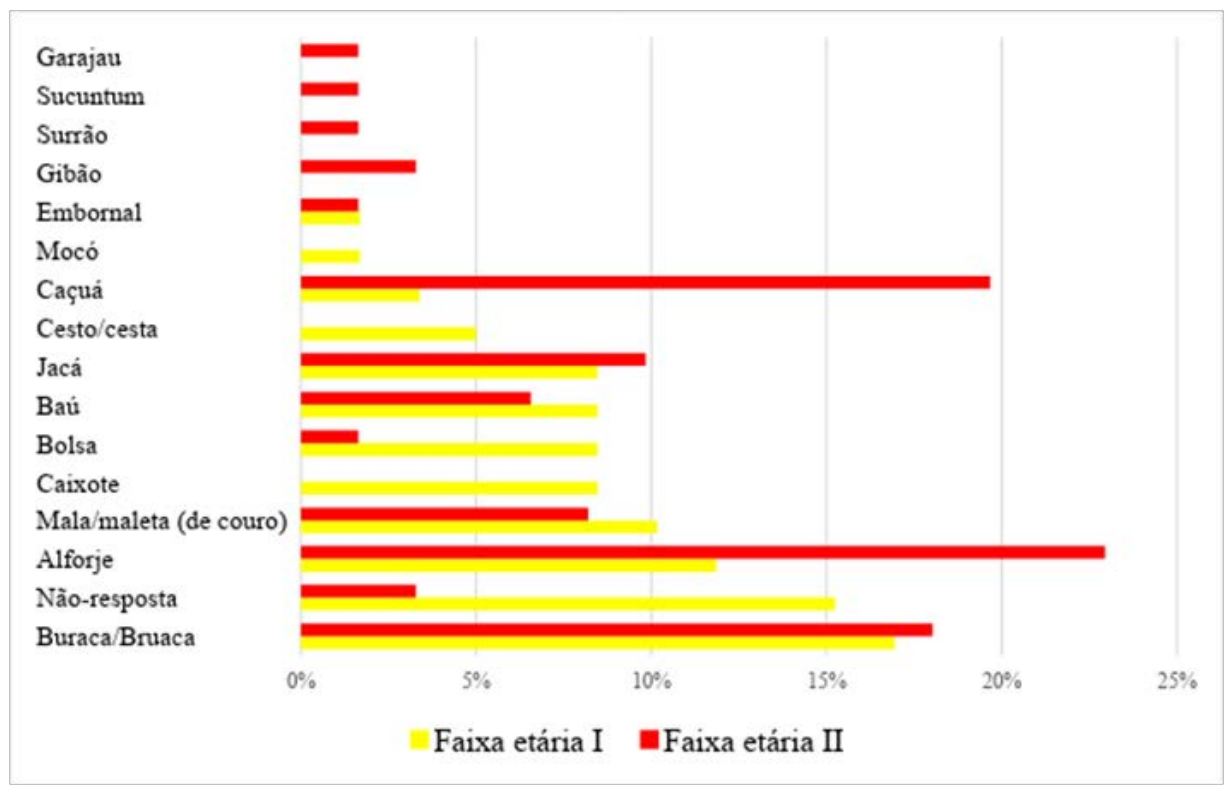

Gráfico 3- Distribuição das variantes por faixa etária (QSL 40). Fonte: elaborado a partir de dados de Silva, 20I8

As citações genéricas ou que se referem a outros elementos são abundantes em ambos os grupos. Interessante que as citações de buraca/bruaca, termos entendidos por Isquerdo (20I0) como elementos vinculados ao universo rural, equiparam-se em ambas as faixas etárias, não apenas nos mais velhos. Acrescenta-se ainda que caixote, cesto/cesta e mocó são de uso exclusivo dos mais jovens, enquanto garajau, sucuntum, surrão e gibão são particulares dos menos jovens.

A distribuição diatópico-diageracional não demonstra aparentes isoglossas ${ }^{2 \mathrm{I}}$ que evidenciem as não respostas. No entanto, nota-se que o extremo norte (Bico do Papagaio) e o sudeste apresentam Ioo\% de respostas para a QSL 40, podendo indicar que nessas regiões ainda se conhecem os elementos do universo rural.

2I Fronteiras virtuais que indicam as áreas em que se concentram determinados traços linguísticos. 


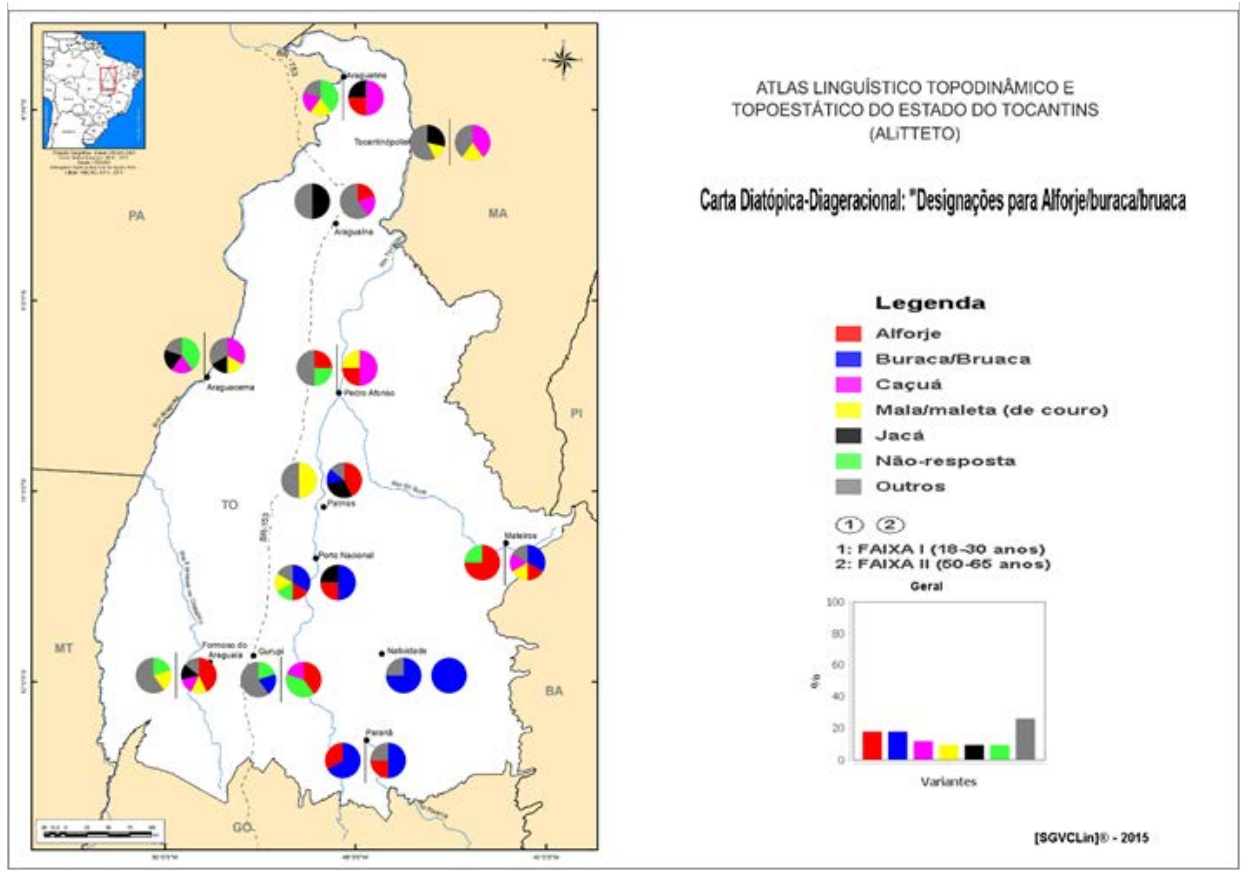

Figura 3-Cartograma diatópico-diageracional. Fonte: dados extraídos de Silva, 20I8

Os maiores índices de não respostas estão em localidades próximas ou às margens da BR-I53, localidades que constituem o eixo de colonização mais recente no estado. Em contrapartida, na parte sudeste do espaço pesquisado, Natividade e Paranã, todos os informantes alegam conhecer o referente, principalmente com a citação de buraca/ bruaca, termos entendidos como Isquerdo (20I0) como marcas de ruralidade.

\section{CONSIDERAÇõES FINAIS}

Em suma, a subárea semântica "Frutas e atividades agropastoris" apresentou índice significativo de não respostas, o que pode ser atribuído ao fato de os referentes pertencerem ao universo ligado à criação de gado. Todavia, os percentuais de não respostas apresentados, se comparados a outros trabalhos, de Isquerdo (20I0), por exemplo, evidenciam no Tocantins um menor índice de desconhecimento dos referentes na subárea em questão.

Observa-se, também, número expressivo de lexias que classificamos como gerais/genéricas - pois podem designar mais de um objeto, não necessariamente o que a questão solicita -, mencionadas, em sua maioria, pelos informantes jovens, possivelmente pelo desuso do objeto no estado.

Cada pergunta apresentou níveis de diferentes de traços de ruralidade. A questão 28, por exemplo, foi a que mais apresentou maior número de não respostas, enquanto a QSL 38 foi a que menos apresentou não respostas. Por fim, a questão 40 apresentou 
relativo índice de não respostas, mas indicou a presença de variados termos genéricos que não necessariamente designam o referente solicitado.

Uma explicação para essa possível disparidade encontra tônica no fato de que, apesar de as três questões estarem inseridas num universo rural, os habitantes do Tocantins demonstram mais conhecimento de referentes ligados, especificamente, à lida com o gado, talvez porque a região seja marcadamente pecuarista, por causa das vastas extensões de área, por isso um léxico mais premente com o gado.

Dessa forma, o Tocantins, por meio das questões analisadas e índice de não respostas, exibe traços de ruralidade, como destacado por Isquerdo (20I0), no Centro-Oeste. Por outro lado, a citação, sobretudo pelos jovens, de itens genéricos nos faz crer que termos mais rurais estão em vias de desaparecimento.

\section{SOBRE AS AUTORAS}

GREIZE ALVES DA SILVA é professora adjunta do curso de Letras da Universidade Federal do Tocantins (UFT), campus de Porto Nacional.

E-mail: greize_silva@yahoo.com.br https://orcid.org/oooo-0002-2589-6750

PATRÍCIA ANDRÉA BORGES é mestranda na área de Semântica e Pragmática no Instituto de Estudos da Linguagem da Universidade Estadual de Campinas (IEL/Unicamp).

E-mail: pattyaborges@gmail.com

https://orcid.org/oooo-0003-3803-4567

\section{REFERÊNCIAS}

ALTENHOFEN, Cléo Vilson; THUN, Harald. As migrações e os contatos linguísticos na geografia linguística do Sul do Brasil e Bacia do Prata. In: AGUILERA, Vanderci de Andrade; ROMANO, Valter Pereira (Org.). A geolinguística no Brasil: caminhos percorridos, horizontes alcançados. Londrina: Eduel, 20I6, p. 37I-392.

AQUINO, Napoleão Araújo de. A construção da Belém-Brasília e suas implicações no processo de urbanização do estado do Tocantins. In: GIRALDIN, Odair (Org.). A (trans)formação histórica do Tocantins. 2. ed. Goiânia: UFG, 2004, p. 3I5-350.

AUGUSTO, Vera Lúcia dias dos Santos. Atlas semântico-lexical do estado de Goiás. Tese (Doutorado). Programa de Pós-Graduação em Semiótica e Linguística Geral, Universidade de São Paulo, 2012. AULETE, Caldas. Dicionário contemporâneo da língua portuguesa. Rio de Janeiro: Delta, I986. 
BARBOSA, Altair Sales; TEIXEIRA NETO, Antônio; GOMES, Horieste. Geografia Goiás-Tocantins. 2. ed. Goiânia: UFG, 2004.

BORTONI-RICARDO, Stella Maris. Do campo para a cidade: um estudo sociolinguístico de migração e redes sociais. São Paulo: Parábola, $20 I I$.

BRASIL. Câmara dos Deputados. Projeto de Lei Complementar PLP I37/20I5. Dispõe sobre o procedimento para a criação, a incorporação, a fusão e o desmembramento de Municípios, nos termos do $§ 4^{\circ}$ do art. I8 da Constituição Federal, altera a Lei n. 5.I72, de 25 de outubro de I966, e dá outras providências. Disponível em: <https://www.camara.leg.br/proposicoesWeb/fichadetramitacao?idProposicao=I594899>. Acesso em 20 fev. 2019.

CARDOSO, Suzana Alice Marcelino et al. Atlas linguístico do Brasil: cartas linguísticas I. Londrina: Eduel, 20I4. CHAMBERS, J. K.; TRUDGILL, Peter. La dialectología. Madrid: Visor, I994.

CRUZ, Maria Luiza de Carvalho. Atlas Linguístico do Amazonas - alam. Tese (Doutorado em Letras Vernáculas). Faculdade de Letras, Universidade Federal do Rio de Janeiro, 2004.

DIÉGUES JÚNIOR, Manuel. Etnias e culturas no Brasil. Rio de Janeiro: Biblioteca do Exército, I980.

FIGUEIREDO, Carla Regina de Souza. Topodinâmica do português gaúcho em áreas de contato intervarietal do Mato Grosso. Tese (Doutorado em Letras). Universidade Federal do Rio Grande do Sul, 20I4.

FREITAS, Luciene Gomes; ISQUERDO, Aparecida Negri. Descrevendo o rural e o urbano no português do projeto ALiB 2008. Relatório final de pesquisa. Campo Grande: Programa Pibic/UFMS, agosto/2008.

GUEDES, Regis José da Cunha. Estudo geossociolinguístico da variação lexical na zona rural do estado do Pará. Dissertação (Mestrado em Linguística). Programa de Pós-Graduação em Letras, Instituto de Letras e Comunicação, Universidade Federal do Pará, 2012.

GUIMARÃES, Eduardo. Verbete: cidade. Enciclopédia ciscursiva da cidade. Campinas: Pontes, 2003. HOUAISS, Antônio. Dicionário Houaiss eletrônico. Instituto Antônio Houaiss. São Paulo: Objetiva, 2009. HOLANDA, Sérgio Buarque de. (I936). Raízes do Brasil. 26. ed. São Paulo: Companhia das Letras, 2004.

ISQUERDO, Aparecida Negri. Revisitando os conceitos de rural e urbano no português do Brasil: contribuições do Projeto ALiB. In: CILPR - CONGRES INTERNATIONAL DE LINGUISTIQUE ET DE PHILOLOGIE ROMANES, 25., 20Io, Innsbruck. Actes... v. IV. Berlim: De Gruyter: 20Io, p. I37-I46.

MARGOTTI, Felício Wessling. O português em contato com o italiano no Sul do Brasil: um estudo geolinguístico pluridimensional. In: AGUILERA, Vanderci de Andrade; ROMANO, Valter Pereira (Org.). A geolinguística no Brasil: caminhos percorridos, horizontes alcançados. Londrina: Eduel, 20I6, p. 355-370.

MARINS, Luciene Gomes Freitas. O léxico rural no Brasil Central: designações para "bruaca”. Estudos Linguísticos, São Paulo, v. 43, n. I, jan.-abr. 20I4 p. 545-560. Disponível em: <https://revistas.gel.org. br/estudos-linguisticos/article/view/458/340 >. Acesso em jan. de 2018.

NASCENTES, Antenor. O linguajar carioca. Rio de Janeiro: Organização Simões, I953.

PALACÍN, Luis; MORAES, Maria Augusta de Sant’Anna. História de Goiás. 7. ed. Goiânia: UCG, 2008.

PENNA, Maura. Relatos de migrantes: questionando as noções de perda de identidade e desenraizamento.

In: SIGNORINI, Inês (Org.). Lingua(gem) e identidade: elementos para discussão no campo aplicado. Campinas: Mercado das Letras, 2006, p. 89-п2.

RIBEIRO, Silvana S. C. Brinquedos e brincadeiras infantis na área do falar baiano. Tese (Doutorado em Letras). Programa de Pós-Graduação em Letras e Linguística, Instituto de Letras, Universidade Federal da Bahia, Salvador, 2012.

ROMANO, Valter Pereira; ISQUERDO, Aparecida Negri. Um estudo rural $x$ urbano na fala do homem urbano: perspectiva geolinguística. In: ENCONTRO CIENTÍFICO DO CURSO DE LETRAS, 5., 2007, Rolândia. Anais... Disponível em: 〈http://www.faccar.com.br/desletras/hist/2007_g/index.html〉. Acesso em: jan. de 2018. 
ROSSI, Nelson; FERREIRA, Carlota; ISENSEE, Dinah. Atlas prévio dos falares baianos. Rio de Janeiro: Ministério de Educação e Cultura; Instituto Nacional do Livro, I963.

SALLES, Gilka Vasconcelos Ferreira de. A economia e a escravidão na capitania de Goiás. Goiânia: Cegraf/ UFG, I992. (Coleção Documentos Goianos, 24).

SILVA, Greize Alves da. Atlas linguístico topodinâmico e topoestático do estado do Tocantins (ALiTTETO). 2018. Tese (Doutorado em Estudos da Linguagem). Programa de Pós-Graduação em Estudos da Linguagem, Universidade Estadual de Londrina, Londrina, 2018.

VEIGA, José Eli. Cidades imaginárias. Campinas: Autores Associados, 2002.

VEIGA, José Eli. Nem tudo é urbano. Ciência e Cultura, São Paulo: SBPC, v. 56, n. 2, abr./jun.2004, p. 26-29.

ZÁGARI, Mário Roberto. Os falares mineiros: esboço de um atlas linguístico de Minas Gerais. In: AGUILERA, Vanderci de Andrade (Org.). A geolinguística no Brasil: caminhos e perspectivas. Londrina: Eduel, I998, p. 3I-77.

ZIAMANDANIS, Claire. La falta de respuesta y el desconocimiento en Puerto Rico: silenciar también es contestar. In: MORALES, Amparo et al. (Org.). Estudios de lingüística hispánica: homenaje a María Vaquero. San Juan: Editorial de la Universidad de Puerto Rico, I999, p. 656-664. 